\title{
Ultramafic xenoliths from the Timiskaming kimberlite cluster, Ontario, Canada
}

\author{
A.K. Follwell ${ }^{1}$, D.J. Schulze ${ }^{2}$, H.H. Helmstaedt ${ }^{1}$, R.C. Peterson ${ }^{1}$ \\ ${ }^{1}$ Department of Geological Sciences and Geological Engineering, Queen's University, Kingston, Ontario, \\ Canada \\ ${ }^{2}$ Department of Geology, University of Toronto, Erindale College, Mississauga, Ontario, Canada
}

\begin{abstract}
A selection of ultramafic mantle xenoliths from three kimberlite diatremes (95-2, KL-22 and MR-8) of the Timiskaming field in Ontario, Canada have been examined in order to characterize this portion of the mantle beneath the Archean Superior Province. The kimberlites intrude Proterozoic Huronian rocks that overlie the southern margin of the Superior craton. These mantle xenoliths provide an estimation of the depth interval and approximate thickness of the lithosphere sampled by the kimberlite during emplacement. Petrographic and mineral compositions were used to classify the xenoliths. The suite is predominantly spinel lherzolite, with lesser amounts of garnet lherzolite, garnet harzburgite, and lherzolite and rare eclogites. The xenoliths are mostly coarse-grained and show evidence of subsequent thermal and metasomatic events, including effects of entrainment in the host kimberlite magma.
\end{abstract}

Preliminary chemical analyses have allowed the temperatures and pressures of equilibration to be estimated for this suite of xenoliths. Geothermometry, as determined from $\mathrm{Fe}-\mathrm{Mg}$ exchange between clinopyroxene and garnet, shows that the xenoliths sampled the mantle over a temperature range of 770 to $960^{\circ} \mathrm{C}$. Corresponding geobarometry, calculated through the $\mathrm{Cr} / \mathrm{Al}$ exchange in clinopyroxene and garnet, indicate that pressure conditions of the mantle lithosphere was within an interval of 30 to $37 \mathrm{kbar}$.

There are several significant differences between the xenolith population of the Timiskaming kimberlites and the Kirkland Lake cluster, approximately 100 kilometres to the north, further from the craton margin. The dominant lithology of the Timiskaming xenoliths is spinel peridotite, whereas the xenolith population from Kirkland Lake is primarily garnet peridotite. This major difference, and the presence of eclogites in the Timiskaming suite, illustrates markedly different mantle compositions beneath these two regions. In addition, the Timiskaming suite seems to lack a high temperature population in contrast to the xenoliths from A-1, A-4 and B-30 kimberlites from Kirkland Lake which are inflected to higher temperatures above a $40 \mathrm{~mW} / \mathrm{m}^{2}$ steady-state conductive geotherm. This suggests that the depth range and maximum depth of the sampled portion of the mantle was shallower in the Timiskaming region than in Kirkland Lake. Such differences suggest a change in character of the subcratonic lithosphere that may be related to proximity to the craton margin. 
